Democracy and Executive Power 
This page intentionally left blank 


\section{Democracy and Executive Power}

Policymaking Accountability in the US, the UK, Germany, and France

Susan Rose-Ackerman

Yale UNIVERSITY PRESS 
Published with assistance from the foundation established in memory of Amasa Stone Mather of the Class of I907, Yale College.

Copyright (C) 202I by Susan Rose-Ackerman.

All rights reserved.

This book may not be reproduced, in whole or in part, including illustrations, in any form (beyond that copying permitted by Sections 107 and I08 of the U.S. Copyright Law and except by reviewers for the public press), without written permission from the publishers.

Yale University Press books may be purchased in quantity for educational, business, or promotional use. For information, please e-mail sales.press@yale.edu (U.S. office) or sales@yaleup.co.uk (U.K. office).

Set in Fournier MT type by IDS Infotech Ltd.

Printed in the United States of America.

Library of Congress Control Number: 2021930104

ISBN 978-0-300-25495-2 (hardcover : alk. paper)

A catalogue record for this book is available from the British Library.

This paper meets the requirements of ANSI/NISO Z39-48-1992 (Permanence of Paper).

I09 87654321 


\section{For Bruce,}

My face in thine eye, thine in mine appears, And true plain hearts do in the faces rest; ...

If our two loves be one, or thou and I

Love so alike, that none do slacken, none can die.

-John Donne, The Good-Morrow 
This page intentionally left blank 